\title{
Lung Large Cell Carcinoma, Clear Cell Variant
}

National Cancer Institute

\section{Source}

National Cancer Institute. Lung Large Cell Carcinoma, Clear Cell Variant. NCI Thesaurus. Code C4451.

A large cell lung carcinoma characterized by a predominance of clear cells that may or may not contain glycogen. 